\title{
Аналіз існуючих підходів до процесу фізичної терапії пацієнтів з неспецифічним болем у попереку
}

\author{
УДК 615.83:616.833.5
}

\author{
А. А. Згурський, Н. В. Чечер
}

Національний університет фізичного виховання і спорту Украини, Київ, Україна

\begin{abstract}
Резюме. Донедавна зарубіжними вченими було виконано численні дослідження, присвячені побудові та ефективності реабілітаційного процесу осіб різних вікових груп з різними проявами неспецифічного болю в попереку, але в жодному з них не описано ефективний, загальноприйнятий фізіотерапевтичний підхід у терапії осіб, які страждають на прояви неспецифічного болю в попереку. Мета. На основі аналізу сучасних наукових та клінічних досліджень проаналізувати існуючі підходи до процесу фізичної терапії осіб працездатного віку з проявами неспецифічного болю в попереку. Методи. Аналіз та узагальнення зарубіжних даних спеціальної науково-методичної літератури, синтез та узагальнення. Результати. Проведений аналіз останніх наукових робіт показав, що існує багато досліджень, які описують фізичні та функціональні показники осіб, які страждають на різні прояви неспецифічного болю в попереку. Зазвичай, це патологія опорно-рухового апарату та периферичної нервової системи. На сьогодні відсутні загальноприйняті фізіотерапевтичні підходи, що мають комплексний характер терапії неспецифічного болю в попереку.

Ключові слова: фізична терапія, реабілітація, неспецифічний біль у попереку.
\end{abstract}

Analysis of existing approaches to physical therapy of patients with nonspecific low back pain

\section{A. A. Zgurskyi, N. V. Checher}

National University of Physical Education and Sport of Ukraine, Kyiv, Ukraine

\begin{abstract}
Until recently, foreign scientists have conducted numerous studies on the design and effectiveness of the rehabilitation process of people of different ages with various manifestations of nonspecific low back pain, but none of them describes an effective, generally accepted physiotherapeutic approach to the treatment of patients suffering from nonspecific low back pain. Objective. Based on the analysis of the current scientific and clinical research, to analyze existing approaches to physical therapy of persons of working age with manifestations of nonspecific low back pain. Methods. Analysis and generalization of foreign data of special scientific and methodical literature, synthesis and generalization. Results. An analysis of recent research has shown that there are many studies that describe the physical and functional characteristics of persons suffering from various manifestations of nonspecific low back pain. Usually, it is pathology of the locomotorium and peripheral nervous system. To date, there are no generally accepted physiotherapeutic approaches that have a complex treatment of non-specific low back pain.
\end{abstract}

Keywords: physical therapy, rehabilitation, nonspecific low back pain.

Постановка проблеми. Біль у попереку вважається однією з найпоширеніших у світі причин звернення за медичною допомогою. Згідно зі статистичними даними, $84 \%$ людей у світі хоч раз у своєму житті зіштовхуються з болем у попереку, 23 \% мають хронічний біль, 11-12 \% вважаються непрацездатними з цієї причини [1]. 3 кожним роком ситуація погіршується, що зумовлено старінням та зростанням населення у світі [15]. В глобальному масштабі скарги на біль у попереку збільшилися на $54 \%$ в період між 1990 і 2015 роками, причому найзначніше 
збільшення спостерігається в країнах з низьким та середнім рівнями доходів [11]. Очікується, що скарги на біль у попереку та збільшення непрацездатності будуть лише зростати. Це пов'язано 3 низьким рівнем якості охорони здоров'я та обмеженими фрінансовими можливостями населення, а тенденція до зростання малорухомого способу життя буде лише збільшувати ризики виникнення болю.

Враховуючи відсутність чіткої кореляції між дегенеративно-дистрофічними змінами хребта, порушеннями постави і неспецифрічним болем у попереку, а також суттєвим впливом психологічних та соціальних фракторів на біль, виникає потреба у вдосконаленні вже існуючих та розробці нових підходів діагностики і терапії таких пацієнтів.

Особливу увагу необхідно приділити клінічному оцінюванню пацієнтів на етапі фрізіотерапевтичного втручання для подальшого реабілітаційного менеджменту відповідно до інтенсивності больового синдрому та обмеження активності.

Біль у попереку $\epsilon$ симптомом, а не хворобою. Відповідно до Європейських рекомендацій запобігання болю в попереку, поперековий біль характеризується як біль або дискомфорт, що локалізується нижче реберних країв і вище нижніх сідничних складок, 3 наявністю болю в ногах чи без нього [3]. В більшості випадків неможливо точно виявити специфічне джерело болю, оскільки всі структури хребта, що мають ноцицептори, можуть викликати його. Саме тому такий вид болю називається неспецифічним. Він діагностується в 90-95\% випадків. До інших причин болю належать специфрічні фрактори, радикулопатії (5-10\%) та більш серйозні патології $(<1 \%)$, перелом, рак чи інфрекція [16].

За даними М. С. Jensen et al. [13], багато людей без болю в спині мають дегенеративно-дистрофрічні зміни хребта, що виявляються на знімках МРТ. Враховуючи високу поширеність змін хребта на МРТ у безсимптомних пацієнтів, виявлення подібних порушень при болю в попереку може бути випадковим, або він $є$ нормальними віковими змінами хребта.

K. Daimon et al. [9] за допомогою МРТ визначили відсутність кореляції між прогресуванням дегенеративних змін шийного відділу хребта та виникненням клінічних симптомів протягом 20 років у початково здорових людей. Лише фрорамінальний стеноз був пов'язаний із больовими синдромами верхньої кінцівки.

S. T. Christensen et al. [5] провели систематичний огляд 54 епідеміологічних досліджень, пов'язаних із впливом змін сагітальних вигинів хребта на здоров'я людини. Зміни не пов'язані 3 погіршенням здоров'я, в тому числі і з неспецифрічним болем у спині. За даними роботи S. W. Chun et al. [6], було виявлено суттєвий зв'язок з болем у попереку та зменшенням поперекового лордозу, особливо в порівнянні з відповідними віковими контрольними групами. Але у наведених дослідженнях автори не враховують вплив психосоціальних фракторів, мобільності хребта та нейром'язового контролю на виникнення болю.

У систематичному огляді Robert A. Laird et al. [18] виявили вплив біомеханічних порушень руху попереково-клубового відділу хребта на біль у попереку. Автори довели зв'язок болю в попереку з порушенням діапазону руху та зменшенням пропріоцепції попереково-клубового відділу хребта.

У роботі Jaap H. van Dieen et al. [12] доведено відмінність нейром'язового контролю та кінематики у пацієнтів з болем у спині в асимптомних групах.

J. Hartvigsen et al. [10] вказують на важливу роль психогенних та соціальних фракторів у фрормуванні неспецифрічного болю в спині та втраті працездатності. Неспецифрічний біль у спині все частіше розуміють як тривалий стан зі змінним перебігом, а не епізодами споріднених явищ. Близько половини людей, які відчували неспецифрічний біль у спині в первинній допомозі, відчувають постійний сильний біль у попереку.

Робота виконується відповідно до плану НДР НУФВСУ на 2016-2020 рр. за темою: 4.2 «Організаційні та теоретико-методичні основи фрізичної реабілітації осіб різних нозологічних, профресійних та вікових груп» (номер держреєстрації 0116U001609).

Мета дослідження - на основі аналізу сучасних наукових та клінічних досліджень проаналізувати існуючі підходи до процесу фрізичної терапії пацієнтів з неспецифічним болем у спині.

Методи дослідження: аналіз та узагальнення зарубіжних даних спеціальної науково-методичної літератури.

Результати дослідження та їх обговорення. Існує багато терапевтичних підходів у лікуванні неспецифічного болю в попереку, включаючи фрізичну терапію, що підтримується кількома систематичними оглядами. Однак жоден із них не прийнятий як найбільш ефективний. Згідно з останніми рекомендаціями терапії неспецифічного болю в спині, не радять передовсім застосовувати медикаментозне та інвазивне лікування [14]. Саме тому фрізична терапія є основним i першочерговим методом лікування таких пацієнтів. Головною метою методів фрізичної терапії $\epsilon$ 
зменшення болю, відновлення нормального руху та фонкції, профрілактика можливих рецидивів у майбутньому. Але існують певні труднощі з вибором дієвих та доцільних підходів лікування, особливо в нашій країні. Це пов'язано з тим, що більшість підходів не враховують вплив психосоціальних фракторів і спрямовані на лікування дегенеративно-дистрофрічних змін, а не відновлення руху та функції з урахуванням рівня активності й участі пацієнта відповідно до Міжнародної класифрікації фрункціонування (ICF). Також більшість спеціалістів нехтує клінічним фрізіотерапевтичним оглядом, на основі якого повинне фоормуватися реабілітаційне втручання.

У зарубіжній літературі для диференціації пацієнтів з неспецифрічним болем у спині застосовують терапевтичну класифрікацію на основі клінічних симптомів [21]. Класифікація пацієнтів поділяється на два етапи: 1) первинна медико-санітарна допомога; 2) фрізіотерапевтичне втручання. На першому етапі виключаються специфрічні фактори болю (червоні прапорці) та серйозні супутні захворювання. Додатково може застосовуватися опитувальник «Keele STarT Back Screening Tool» для виявлення психосоціальних фракторів, що можуть вплинути на результат та час відновлення [2].

На етапі первинної медико-санітарної допомоги більшість пацієнтів потребуватимуть реабілітаційного втручання. На другому етапі пацієнтів класифікують відповідно до інтенсивності больового синдрому та обмеження активності для подальшого реабілітаційного менеджменту. На основі клінічних проявів пацієнтів класифікують на три групи: модуляція симптомів, контроль руху та функціональна оптимізація. Але такий підхід неефективний у терапії хронічного неспецисрічного болю в попереку. Висновки систематичного огляду Ferran CUENCA-MARTHNEZ et al. [8] свідчать, що застосування класичних методів фрізичної терапії не дає суттєвих терапевтичних ефректів у лікуванні хронічного неспецифічного болю в попереку. Це пов'язано з відсутністю системи підкласифрікації пацієнтів з периферичною та центральною сенситизацією болю. Необхідні додаткові дослідження для кращого розуміння стратегій терапії цих станів, включаючи біопсихосоціальну парадигму.

N. E. Foster et al. [22] рекомендують при гострому неспецифічному болю застосовувати поради із самоконтролю, освітні програми, спрямовані на розуміння причин болю, та рекомендують залишатися максимально активними. Але в Україні такий підхід дуже часто не сприймається пацієнтами у зв'язку з хибними уявленнями про причини болю.
R. Chou et al. [4] довели ефективність застосування методів мануальної терапії, фрізичних вправ та поверхневого тепла. Необхідно брати до уваги специфіку застосування пасивних методів терапії. Наприклад, потрібно враховувати короткострокову дію мануальної терапії та ризики звикання пацієнтів до такого виду лікування неспецифічного болю в спині, оскільки використання лише таких методів може призводити до погіршення стану в довгостроковій перспективі. Особливу увагу необхідно приділяти словам, якими терапевт пояснює терапевтичну дію методів мануальної терапії.

Висновки систематичного огляду I. D. Coulter et al. [7] про ефективність застосування мануальної терапії при хронічному неспецифрічному болю у спині свідчать про помірні докази його зменшення та покращення фрункції. Проте автори не брали до уваги ефективність мобілізації в русі, а аналізували ефективність лише пасивної мобілізації та маніпуляції.

3-поміж усіх методів фрізичної терапії застосування фрізичних вправ вважається найбільш ефективним та доказово обгрунтованим. Більшість вправ дають позитивний результат у довгостроковій перспективі. Але не існує конкретних специфічних вправ при неспецифрічному болю у спині, що створює певну плутанину на етапі реабілітаційного менеджменту. Наприклад, у дослідженні B. E. Smith et al. [20] доведено відсутність переваг вправ на стабілізацію м'язів порівняно з іншими формами фрізичної активності. В іншому дослідженні [19] учені також не знайшли переваг вправ на покращення нейром'язового контролю над іншими видами фрізичних навантажень. У цілому більшість видів ффізичної активності дають позитивні терапевтичні результати після шести місяців систематичних занять. Тому під час вибору фрізичних вправ при неспецисрічному болю у спині необхідно враховувати інтенсивність симптомів, рівень фрізичного та психологічного стану пацієнта, його вподобання щодо вибору фрізичного навантаження.

Ученими було доведено, що якщо сфокусувати увагу поза результатом болю, то опір і стабілізація фрізичної вправи сприятимуть управлінню опорно-руховим апаратом. Форми тренувань матимуть найбільший вплив на поліпшення фрізичного стану. Крім цих способів, значний ефрект (тобто $>0,8$ ) буде на користь зменшення інвалідності, що спостерігалося також після вправ з йоги, пілатесу, на воді та аеробних вправ. Учені свідчать, що ряд режимів тренувань сприяє зменшенню інвалідності у пацієнтів з неспециорічним болем у попереку. Фізичні терапевти, які призна- 
чають фрізичні вправи, повинні працювати з пацієнтами до визначення мобільності, відповідної їнім можливостям, інтересам, та підвищувати ймовірність ефективності [17].

Сила та витривалість м'язів тулуба - відомі фактори ризику для майбутнього болю у спині. Незважаючи на клінічну актуальність, це дослідження надало незначні докази того, що стійкість і стабілізація терапевтичних вправ можуть покращити силу м'язів тулуба, ефективність цих втручань порівняно з контрольним втручанням. Сила та витривалість м'язів тулуба мають потенціал бути об'єктивними заходами для диференційованого лікування, а майбутні випробування повинні включати їх заходи до з'ясування ефективності тренувальних занять.

За даними учених, різні підходи до фрізичного навантаження $€$ ефективними та повинні бути включені до звичного догляду за дорослими з неспецифічним болем у попереку через його потенціал для поліпшення фрізичної функції, сили м'язів і психічного здоров'я [19]. Важливо, щоб тренування було більш ефективним, ніж практичне лікування терапевта, для зменшення болю, поліпшення фрізичної функції та психічного здоров'я.

Вивчення конкретних видів тренувальних занять було обмеженим за кількістю наявних досліджень та мінливістю у звітності. Були незначні докази того, що справжній контроль (тобто відсутність втручання), робота терапевта (наприклад, лікар загальної практики управління, навчання або психологічні втручання) та фрізичного терапевта (наприклад, мануальна терапія, хіропрактика чи пасивна фрізіотерапія), швидше за все, - неефективні втручання для неспецифіч-

\section{Література}

1. Balagué F1, Mannion AF, Pellisé F, Cedraschi C. Non-specific low back pain. Lancet. 2012 Feb 4;379(9814):482-91.

2. Beneciuk JM, Bishop MD, Fritz JM, Robinson ME, Asal NR, Nisenzon AN and George SZ. 'The STarT Back Screning Tool and individual psychological measures: evaluation of prognostic capabilities for low back pain clinical outcomes in outpatient physical therapy settings' Physical Therapy.

3. Burton AK. European. guidelines for prevention in low back pain. COST B13 Working Group. 2004. 1-53. (Level 1A).

4. Chou R, Côté P, Randhawa K, Torres P, Yu H, Nordin M, Hurwitz EL, Haldeman S, Cedraschi C. Eur Spine J. 2018 Sep;27(Suppl 6):851-860. doi: 10.1007/s00586-017-5433-8. Epub 2018 Feb 19.

5. Christensen ST1, Hartvigsen J. (2008) J Manipulative Physiol Ther. 2008 Nov-Dec;31(9):690-714. doi: 10.1016/j.jmpt.2008.10.004.

6. Chun SW, Lim CY, Kim K, Hwang J, Chung S (2017) Spine J. 2017 Aug;17(8):1180-91. doi: 10.1016/j.spinee.2017.04.034. Epub 2017 May 2.

7. Coulter ID, Crawford C, Hurwitz EL, Vernon H, Khorsan R, Suttorp Booth M, Herman PM 2018 Spine J. 2018 May;18(5):866-79. doi: 10.1016/j. spinee.2018.01.013. Epub 2018 Jan 31.

8. Cuenca-Martínez F, Cortés-Amador S, Espí-López GV. Effectiveness of classic physical therapy proposals for chronic non-specific low back pain: a ного болю у попереку. Існували деякі докази позитивного впливу тренування на розтяжку, тобто те, що пілатес чинить позитивну дію на стабілізацію / руховий контроль, заняття аеробними вправами сприяють зменшенню болю, підвищенню фрізичної функції та психічного здоров'я у людей з неспецифічним болем у попереку. 3 огляду на сказане, можна зробити висновки, що активна терапія може бути ефективним лікуванням неспецифрічного болю в попереку [17].

Висновки. Донедавна зарубіжними вченими було виконано численні дослідження, присвячені побудові та ефективності реабілітаційного процесу осіб різних вікових груп з різними проявами неспецифічного болю в попереку, але в жодному з них не описано ефективний, загальноприйнятий фрізіотерапевтичний підхід у терапії осіб, які страждають на прояви неспецифрічного болю в попереку.

Існує велика кількість терапевтичних підходів до неспецифічного болю у попереку, в тому числі і фрізіотерапевтичних, але згідно з останніми статистичними данними, це не допомагає вирішити проблему. Причиною можуть бути хибні уявлення як у медичних працівників, так і у пацієнтів про методи діагностики та лікування цього болю, нехтування впливом психосоціальних фракторів, особливо при хронічному болю, надмірний акцент на стуруктурних змінах хребта та біомеханічних порушеннях, що не відповідає сучасним науковим даним. Саме тому виникає необхідність у розробці нових та вдосконаленні існуючих підходів оцінювання пацієнтів на етапі реабілітаційного втручання, на основі яких буде будуватися відповідна комплексна програма фрізичної терапії.

literature review. Phys Ther Res. 2018;21(1):16-22. Published 2018 Mar 20 doi:10.1298/ptr.E9937

9. Daimon K, Fujiwara H, Nishiwaki Y, Okada E1, Nojiri K, Watanabe M, Katoh H, Shimizu K, Ishihama H, Fujita N, Tsuji T, Nakamura M, Matsumoto M, Watanabe K. (2018) J Bone Joint Surg Am. 2018 May 16;100(10):843-49. doi: 10.2106/JBJS.17.01347.

10. Hartvigsen J, Hancock MJ, Kongsted A, et al. [Hartvigsen J, Hancock $\mathrm{MJ}$, Kongsted A, et al. What low back pain is and why we need to pay attention. Lancet 2018;391:2356-67.

11. GBD 2016 Disease and Injury Incidence and Prevalence Collaborators. Global, regional, and national incidence, prevalence, and years lived with disability for 328 diseases and injuries for 195 countries, 1990-2016: a systematic analysis for the Global Burden of Disease Study 2016. Lancet. 2017;390:1211-59.

12. Jaap H. van Dieen, N. Peter Reeves, Greg Kawchuk, Linda R. van Dillen and Paul W. Hodges (2018), [Sports Phys Ther. 2019;49(6):370-379. Epub 12 Jun 2018. doi:10.2519/jospt.2019.7917.

13. Jensen MC, Brant-Zawadzki MN, Obuchowski N, Modic MT, Malkasian D, Ross JS. (1994) N Engl J Med. 1994 Jul 14;331(2):69-73.

14. Jorgensen JE, Afzali T, Riis A. Effect of differentiating exercise guidance based on a patient's level of low back pain in primary care: a mixed-meth- 
ods systematic review protocol. BMJ Open. 2018;8(1):e019742. doi: 10.1136/ bmjopen-2017-019742.

15. Lancet. 2017 Oct 28;390(10106):e38. doi: 10.1016/S01406736(17)32647-8. Epub 2017 Oct 13.

16. Lynn D Bardin, Peter King and Chris G Maher Med J Aust 2017;206(6): 268-73. doi: $10.5694 / \mathrm{mja} 16.00828$.

17. Patrick J Owen, Clint T Miller, Niamh L Mundell, Simone JJM Verswijveren, Scott D Tagliaferri, Helena Brisby, Steven J Bowe, Daniel L Belavy. Which specific modes of exercise training are most effective for treating low back pain? Network meta-analysis. Sports Med 2019;0:1-12. doi:10.1136/ bjsports-2019-100886.

18. Robert A Laird, Jayce Gilbert, Peter Kent and Jennifer L Keating (2014) BMC Musculoskeletal Disorders.2014.15:229.

physiorehabkyiv@gmail.com

checher427@gmail.com
19. Saragiotto BT, Maher CG, Yamato TP, Costa LO, Menezes Costa LC, Ostelo RW, Macedo LG. Cochrane Database Syst Rev. 2016 Jan 8;(1):CD012004. doi: 10.1002/14651858.CD012004.

20. Smith BE, Littlewood C, May S BMC Musculoskelet Disord. 2014 Dec 9;15:416. doi: 10.1186/1471-2474-15-416.

21. Therapy P. The Treatment-Based Classification System for Low Back Pain : Revision and Update, (December). https://doi.org/10.2522/ptj.20150345 22. Foster NE, Anema JR, Cherkin D, Chou R, Cohen SP, Gross DP, et. al Lancet Low Back Pain Series Working Group Prevention and treatmen of low back pain: evidence, challenges, and promising directions. Lancet. 2018;391(10137):2368-83. doi: 10.1016/S0140-6736(18)30489-6. 